\title{
PROVENANCE OF PINDOS FORELAND FLYSCH DEPOSITS USING SCANNING ELECTRON MICROSCOPY AND MICROANALYSIS
}

\author{
Vakalas I. ${ }^{1}$, Ananiadis G. ${ }^{1}$, Zelilidis A. ${ }^{1}$, Kontopoulos N. ${ }^{1}$ and Tsikouras B. ${ }^{2}$ \\ ${ }^{1}$ Laboratory of Sedimentology, Department of Geology, University of Patras, 26500, Patra, \\ Greece,ivakalas@upatras.gr, gananiad@upatras.gr, a.zelilidis@upatras.gr, \\ kontopou@upatras.gr \\ ${ }^{2}$ Section of Earth Materials, Department of Geology, University of Patras, 26500, Patra, Greece, \\ v.tsikouras@upatras.gr
}

\begin{abstract}
A number of polished thin sections from two cross sections within the Pindos foreland deposits were petrographically examined while microanalyses on certain minerals were carried out. Chemistry of these minerals is compared to analogous phases occurring in several formations in the neighbourhood of the studied areas which can stand as source areas. Our results reveal that the most probable source materials include the Pindos, Koziakas (and probably and Vourinos) ophiolite complexes, as well as metamorphic sequences of the Pelagonian Zone.
\end{abstract}

\section{INTRODUCTION}

The flysch deposits of Pindos foreland (Fig. 1) have been interpreted as submarine fan deposits (Piper et al, 1978). Interpretation of palaeocurrent data and facies distributions (British Petroleum, 1970; Piper et al., 1978; Alexander et al., 1990) indicates that the provenance of Pindos foreland turbiditic deposits is the Pindos thrust belt to the east. Alexander et al. (1990) working on the conglomeratic deposits in the study area suggested, based on the composition of the conglomeratic clasts, that the origin of these deposits is located eastwards in the Pindos zone. Faupl et al. (1999) suggested also that the clastic material has an eastwards origin, examining heavy mineral distribution of samples deriving from turbiditic successions of Ionian, Gavrovo, Pindos and Parnassos-Ghiona zones. Flow within the basin was mainly axial (Richter et al., 1978; Leigh, 1991; Vakalas et al., 2001) with some perpendicular directions (Vakalas et al., 2001).

Determination of the source areas which fed the Pindos foreland basin (Fig. 1) with clastic sediment, during Tertiary, was based on the examination of polished thin sections of sandstone turbiditic beds, under polarizing and scanning electron microscope, as well as by performing microanalyses in certain minerals.

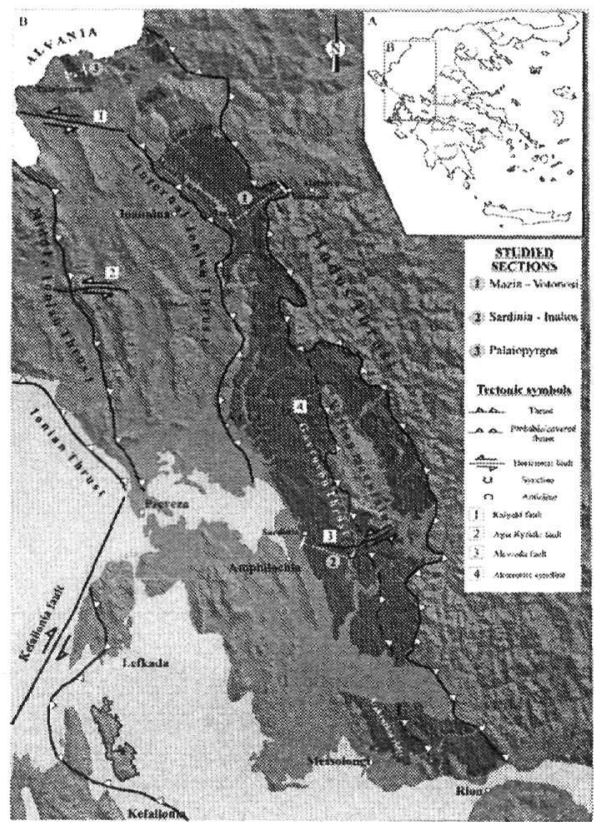

Figure 1. Simplified geological map showing the studied cross-sections. These beds have an average thickness of $15 \mathrm{~cm}$ and are characterized by the presence of the subdivision Ta of Bouma sequence. The sampling area covers two geological cross section located in Mazia-Votonosi road (Epirus region) and in SardiniaInahos river road (Akarnania region), respectively. 


\section{METHODOLOGY}

The sampling area covers two geological cross section located in Mazia-Votonosi road (Epirus region) and in Sardinia-Inahos river road (Akarnania region) respectively. Polished thin sections were prepared for petrographic investigation and microanalytical work on certain minerals (feldspars, spinels, chlorites, tourmalines, titanites, muscovites, epidotes). Microanalyses were performed using a Jeol JSiM-6300 SEM equipped with EDS and WDS, with accelerating voltage of $20 \mathrm{kV}$ and a beam current of $3 \mathrm{nA}$, in the Laboratory of Electron Microscopy and Microanalysis, University of Patras. The results were compared with other similar data deriving from possible source rock areas.

\section{PETROGRAPHY}

The collected sandstone samples from both the Mazia-Votonosi and Sardinia-Inahos sections contain mainly quartz, alkali feldspars, plagioclase and minor muscovite. Detrital grains and lithic fragments are quite abundant in the first area (up to 60\%) but are less frequent in the second one $(<25 \%)$. The observed detrital grains include spinel, titanite, olivine, apatite, zircon, plagioclase, Kfeldspar (including microcline), epidote, chlorite and tourmaline (only in the Sardinia-Inahos). The lithic fragments comprise serpentinites, basaltic rocks (usually displaying typical oceanic alteration), polycrystalline quartz, cherts, granitic rocks (sometimes with perthitic crystals and/or granophyric textures) and low-grade metapelitic rocks. The grains are cemented usually with micritic calcite while local sparite occurs, too.

\section{MINERAL CHEM:STRY}

\subsection{Alkali feldspars}

Twenty six spots analyses of alkali feldspars were performed from both the Sardinia-Inahos and Votonosi-Mazia sections (Table 1). Plot of the analysed crystals on a ternary Or-Ab-An diagram shows that most of them are rich in orthoclase content (Fig. 2). Few crystals contain significant $A b$ contents and plot in the area of high-temperature alkali feldspars thus advocating for an origin from volcanic rocks (Fig. 2).

Table 1: Representative feluspars microanalyses from the Sardinia - Inahos (A) and Mazia- Votonosi (MB) sections (-: below detection limit).

\begin{tabular}{|c|c|c|c|c|c|c|c|c|c|}
\hline Sample & $A 4 / 1 / 2$ & $4 / 2 / 8 /$ & $7 / 3 / 4 /$ & 5/6/3 & $\mathrm{MB} 3 / 4 / 7$ & MB15/1/2 & MB15/4/8 & $\mathrm{A} 1 / 1 / 3$ & $\mathrm{~A} 4 / 4 / 8$ \\
\hline $\mathrm{SiO}_{2}$ & 64,09 & 64,83 & 65,91 & 64,54 & 63,69 & 65.88 & $3 \quad 69.59$ & $9 \quad 54,88$ & $3 \quad 67,61$ \\
\hline $\mathrm{TiO}_{2}$ & 0,37 & 0,75 & - & - & & - & - & - & . \\
\hline $\mathrm{Al}_{2} \mathrm{O}_{3}$ & 18,58 & 18,79 & 17,92 & 17,66 & 17,88 & 22.24 & 20.12 & 28,57 & 20,58 \\
\hline $\mathrm{FeO}_{\mathrm{t}}$ & - & - & - & - & - & - & - & - & - \\
\hline $\mathrm{CaO}$ & - & 0,52 & - & - & - & 3.43 & 0.35 & 10,34 & 0,79 \\
\hline $\mathrm{Na}_{2} \mathrm{O}$ & 0,61 & 1,57 & 1,58 & 2,50 & 0,34 & 7.41 & 10.07 & 5,30 & 11,17 \\
\hline $\mathrm{K}_{2} \mathrm{O}$ & 15,64 & :3,92 & 15,58 & 14,05 & 16,16 & - & 0.16 & - & - \\
\hline Total & 99,29 & 100,38 & 100,99 & 98,75 & 98,07 & 98,96 & 100,29 & 99,09 & 100,9 \\
\hline \multicolumn{10}{|c|}{ Structural formulae on the basis of 80} \\
\hline \multirow{3}{*}{$\underset{\mathrm{Al}^{\mathrm{N}}}{\mathrm{Si}}$} & 2,98 & 2,96 & 3,01 & 3,01 & 3,00 & 2,901 & 3,009 & 2,488 & 2,941 \\
\hline & 0,02 & 0,04 & - & - & - & 0,099 & - & 0,512 & 0,059 \\
\hline & 3,00 & 3,00 & 3,01 & 3,01 & 3,00 & 3.000 & 3,009 & 3,00 & 3,00 \\
\hline$A l^{v i}$ & 1,00 & 0,97 & 0,97 & 0,97 & 0,99 & 1,044 & 1,025 & 1,013 & 0,995 \\
\hline $\mathrm{Ti}$ & 0,01 & 0,03 & - & - & - & - & - & - & - \\
\hline $\mathrm{Fe}^{\mathrm{t}}$ & - & 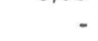 & - & - & - & - & - & - & - \\
\hline $\mathrm{Ca}$ & - & 0,03 & - & - & - & 0,163 & 0,016 & 0,502 & 0,037 \\
\hline $\mathrm{Na}$ & 0,06 & 0,14 & 0,14 & 0,23 & 0,03 & 0,638 & 0,844 & 0,466 & 0,942 \\
\hline $\mathrm{K}$ & 0,93 & 0,81 & 0,91 & 0,84 & 0,97 & - & 0,009 & - & - \\
\hline$A b$ & 5,60 & 14,24 & 13,35 & 21,30 & 3,09 & 79,65 & 97,12 & 48,14 & 96,22 \\
\hline An & 0,00 & 2,56 & 0,00 & 0,00 & 0,00 & 20,35 & 1,84 & 51,86 & 3,78 \\
\hline Or & 94,40 & 83,20 & 86,65 & 78,70 & 96,91 & 0,00 & 1,04 & 0,00 & 0,00 \\
\hline
\end{tabular}




\subsection{Plagioclases}

Representative microanalyses from detrital plagioclase crystals are listed in Table 1. Plot on the Or-Ab-An diagram shows that most of the crystals from the Mazia - Votonosi section are albites while few crystals are of oligoclase to andesine composition. The analysed crystals from the Sardinia - Inahos section display a different compositional pattern: there is a wide compositional range, from pure albite ip to $\mathrm{An}_{54}$ (Fig. 2). The albitic crystals could have been derived either from metapelitic rocks or from altered basaltic rocks from ophiolitic sequences that exist in the broad area. The chemistry of the rest crystals is comparable to analogous crystals from igneous rocks of acid to intermediate composition and/or from amphibolites (of the subophiolitic metamorphic sole). Distinctly one analysed crystal is anorthite (Fig. 2). Such plagioclases can be fractionated only by a hydrous magma of primitive arc-tholeiitic composition (e.g. Wilson, 1989) and are commonly present in gabbroic and ultramafic rocks that are related to SSZ regime; such plagioclases occur in both Pindos and Koziakas gabbros.
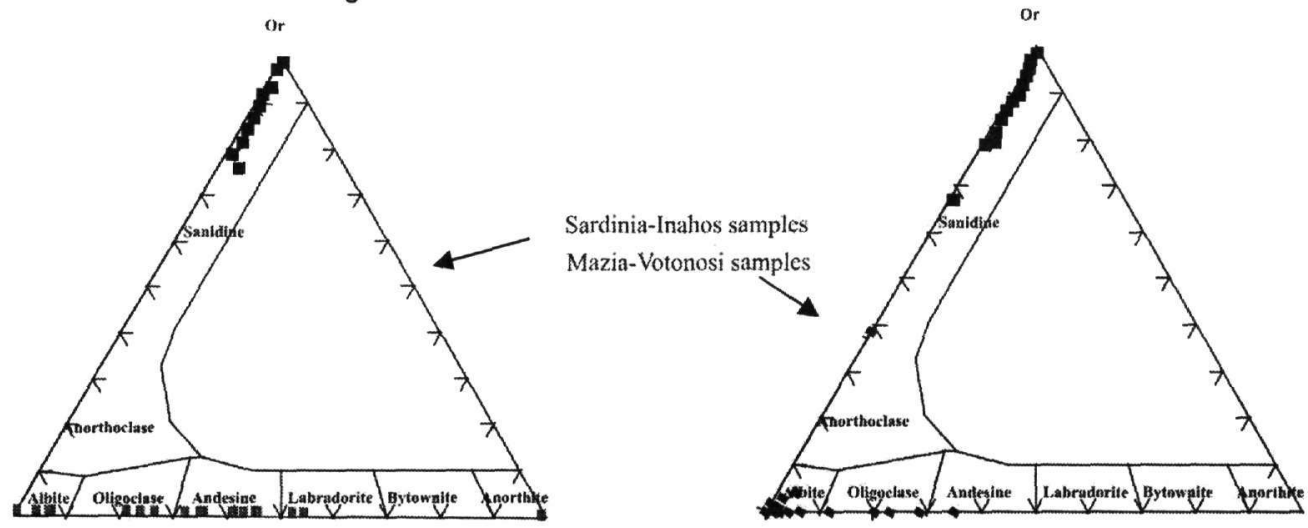

Figure 2. Plot of the analysed feldspars on the Ör-Ab-An diagram

\subsection{Spinels}

Detrital spinels wer€ recognised within samples from both the investigated areas (Table 2). It is well know that spinels are typical minerals occuring in ophiolite complexes. Two groups of spinels were recognised in the samples from the MaziaVotonosi section: a group rich in $\mathrm{Cr}$ and a group poorer in $\mathrm{Cr}$ (Fig. 3). The analysed crystals from the Sardinia-Inahos section are similar to the secorid group of spinels (Fig. 3). All samples are analogous to spinels from the Pindos ultramafic rocks while the rich in $\mathrm{Cr}$ spinels fron the MaziaVotonosi section are also comparable to spinels occuring in the Vourinos ophiolite (Fig. 3).

\subsection{Tourmalines}

Tourmaline comprises a stable mineral that commonly exists in pelitic rocks as well as in granites, throughout the Pelagonian zone, the Attic-

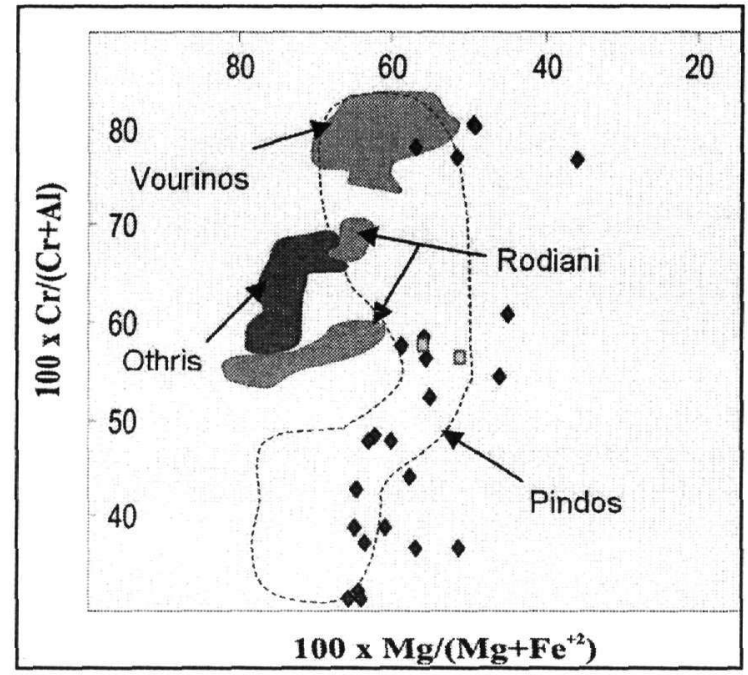

Figure 3: Composition of the analyzed spinels from MaziaVotonosi (diamonds) and Sardinia-Inahos (squares) sections. For comparison fields defined by spinels from Pindos, Othris Vourinos and Rodiani ophiolites are shown (data from Economou et al. 1986, 1995, 1999, Gartzos et al. 1990 and Migiros et al. 1991). 
Cycladic and the Serbomacedonian Zone in Greece. Detrital tourmaline has only found in samples from the Sardinia-Inahos section. Representative tourmaline analyses from that area are given in Table 3. B was calculated of based on a stoichiometric basis. The analysed tourmalines show cohesive results and are poor in Ca contents; therefore they can be compared to analogous crystals originating from metapelitic rocks (Fig. 4). Absence of published tourmaline data does not enable us to compare our analyses to other ones. We only can state that metapelitic rocks from the Pelagonian zone could stand as candidate sources, since it is the spatially closest region where tourmaline occurs in Greece.

Table 2. Representative spinel microanalyses from the Mazia- Votonosi (MB) and Sardinia - Inahos (A) sections (-: below detection limit).

\begin{tabular}{|c|c|c|c|c|c|c|}
\hline Sample & MB14 & MB14 & MB14 & MB14 & $A 7$ & A7 \\
\hline Spot & 5 & 7 & 61 & 4 & 2 & 2 \\
\hline Pos. & 2 & 3 & 1 & 2 & 1 & 2 \\
\hline $\mathrm{SiO}_{2}$ & 0.56 & j.48 & 0.71 & 0.72 & 0.62 & 0.36 \\
\hline $\mathrm{TiO}_{2}$ & 0.15 & 0.26 & 0.17 & 0.05 & 0.28 & - \\
\hline $\mathrm{Al}_{2} \mathrm{O}_{3}$ & 23.20 & 19.36 & 34.64 & 40.36 & 22.68 & 22.54 \\
\hline $\mathrm{Cr}_{2} \mathrm{O}_{3}$ & 42.18 & 44.72 & 29.75 & 27.44 & 43.76 & 45.44 \\
\hline $\mathrm{FeO}^{\mathrm{t}}$ & 23.25 & 24.54 & 22.63 & 15.25 & 19.58 & 17.00 \\
\hline $\mathrm{MnO}$ & 0.38 & 0.26 & 0.25 & 0.29 & - & 0.30 \\
\hline $\mathrm{MgO}$ & 9.37 & 9.23 & 10.99 & 14.23 & 11.50 & 12.12 \\
\hline $\mathrm{CaO}$ & 0.24 & 0.27 & 0.15 & 0.15 & 0.15 & - \\
\hline $\mathrm{Na}_{2} \mathrm{O}$ & 0.19 & 0.25 & 0.20 & 0.27 & 0.71 & 1.08 \\
\hline \multirow[t]{2}{*}{$\mathrm{K}_{2} \mathrm{O}$} & - & - & - & - & - & - \\
\hline & 99.52 & 99.37 & 99.49 & 98.76 & 99.28 & 98.84 \\
\hline \multicolumn{7}{|c|}{ Structural formulae on the basis of 320} \\
\hline $\mathrm{Si}$ & 0.142 & 0.124 & 0.169 & 0.165 & 0.155 & 0.090 \\
\hline Al & 6.908 & 5.901 & 9.736 & 10.860 & 6.676 & 6.634 \\
\hline $\mathrm{Cr}$ & 8.422 & 9.140 & 5.607 & 4.951 & 8.638 & 8.968 \\
\hline $\mathrm{Fe}^{+3}$ & 0.499 & 0.784 & 0.457 & 0.015 & 0.478 & 0.308 \\
\hline Ti. & 0.029 & 0.051 & 0.031 & 0.009 & 0.053 & - \\
\hline $\mathrm{O}$ & 16.000 & 16.000 & 16.000 & 16.000 & 16.000 & 16.000 \\
\hline $\mathrm{Fe}^{+2}$ & 4.417 & 4.527 & 4.060 & 2.899 & 3.615 & 3.245 \\
\hline $\mathrm{Mn}$ & 0.081 & 0.057 & 0.051 & 0.056 & - & 0.064 \\
\hline $\mathrm{Mg}$ & 3.532 & 3.561 & 3.910 & 4.847 & 4.285 & 4.516 \\
\hline $\mathrm{Ca}$ & 0.065 & 0.075 & 0.038 & 0.037 & 0.040 & - \\
\hline $\mathrm{Na}$ & 0.093 & 0.125 & 0.093 & 0.012 & 0.344 & 0.523 \\
\hline $\mathrm{K}$ & - & - & - & - & - & - \\
\hline
\end{tabular}

\subsection{Epidotes}

Only four epidote crystals were feasible to analyse from Sardinia-Inahos section since most of the observed crystals yiusted low quality analyses probably due to secondary effects (Table 4). The Ps content in these crystals range from 14.8 to 25 and when plot on a $\mathrm{Fe}^{\mathrm{t}} \mathrm{vs}$. $\mathrm{Al}^{\mathrm{V} /}$ diagram they form a rather cohesive trend similar to that defined by epidotes from amphibolites, gabbros and basalts in the Koziakas ophiolite (Fig. 5). 
Table 3. Representative detrital tourmaline analyses from the from the Sardinia - Inahos section (-: below detection limit).

\begin{tabular}{|c|c|c|c|}
\hline Sample & A7 & A4 & A4 \\
\hline Spot & 3 & 6 & 2 \\
\hline Pos. & 3 & 2 & 6 \\
\hline $\mathrm{SiO}_{2}$ & 36.87 & 37.56 & 36.77 \\
\hline $\mathrm{TiO}_{2}$ & - & 0.82 & - \\
\hline $\mathrm{B}_{2} \mathrm{O}_{3}$ & 10.61 & 10.75 & 10.65 \\
\hline $\mathrm{Al}_{2} \mathrm{O}_{3}$ & 32.52 & 30.73 & 32.62 \\
\hline $\mathrm{FeO}$ & 7.05 & 5.66 & 5.79 \\
\hline $\mathrm{MnO}$ & - & - & - \\
\hline $\mathrm{MgO}$ & 6.55 & 7.97 & 7.58 \\
\hline $\mathrm{CaO}$ & - & 1.67 & - \\
\hline $\mathrm{Na}_{2} \mathrm{O}$ & 2.76 & 2.48 & 2.79 \\
\hline $\mathrm{K}_{2} \mathrm{O}$ & - & - & - \\
\hline Total & 96.36 & 97.64 & 96.20 \\
\hline \multicolumn{4}{|c|}{ Structural formulae on the basis of 310} \\
\hline B & 3.000 & 3.000 & 3.000 \\
\hline $\mathrm{Si}$ & 6.040 & 6.075 & 6.004 \\
\hline Al & 6.278 & 5.857 & 6.277 \\
\hline $\mathrm{Ti}$ & - & 0.100 & - \\
\hline $\mathrm{Fe}^{+2}$ & 0.966 & 0.765 & 0.791 \\
\hline $\mathrm{Mn}$ & - & - & - \\
\hline $\mathrm{Mg}$ & 1.600 & 1.922 & 1.845 \\
\hline $\mathrm{Ca}$ & - & 0.289 & - \\
\hline $\mathrm{Na}$ & 0.877 & 0.778 & 0.883 \\
\hline $\mathrm{K}$ & - & - & - \\
\hline
\end{tabular}

Figure 4. Composition of st died turmalines in relation with $\mathrm{Al}, \mathrm{Mg}$, $\mathrm{Fe}$ and $\mathrm{Ca}$ ions (after Henry \& Guidotti, 1985). Fields represent: 1) Li-rich granitoid pegmatites and aplites, 2) Li-poor granitoids and associated pegmatites and aplites, 3) $\mathrm{Fe}^{+3}$-rich quartz tourmaline rocks, 4) Metapelites and metapsammites coexisting with an Al- saturating phase, 5) Metapelites and metapsammites not coexisting with an Al- saturating phase, 6) $\mathrm{Fe}^{+3}$ - rich quartztourmaline rocks calc-silicate rocks and metapelites, 7) Low-Ca meta-ultramafics and $\mathrm{Cr}$ - $\mathrm{V}$-rich metasediments, 8) Metacarbonates and metapyroxenites, 9) $\mathrm{Ca}$ rich metapelites, 10) Ca-poor metapelites, metapsammites and quartz-tourmaline rocks.
Table 4. Epidote analyses from the Sardinia - Inahos (A) sections (-: below detection limit).

\begin{tabular}{|c|c|c|c|c|}
\hline Sample & $\mathrm{A} 1$ & $\mathrm{~A} 1$ & $\mathrm{~A} 1$ & $\mathrm{~A} 1$ \\
\hline Spot & 3 & 4 & 5 & 8 \\
\hline Pos. & 8 & 1 & 2 & 1 \\
\hline $\mathrm{SiO}_{2}$ & 39,24 & 40,02 & 40,35 & 39,49 \\
\hline $\mathrm{TiO}_{2}$ & - & 0,09 & - & 2,19 \\
\hline $\mathrm{Al}_{2} \mathrm{O}_{3}$ & 23,33 & 24,50 & 27,65 & 22,46 \\
\hline $\mathrm{Fe}_{2} \mathrm{O}_{3}$ & 10,70 & 9,53 & 6,77 & 10,61 \\
\hline $\mathrm{Cr}_{2} \mathrm{O}_{3}$ & 0,32 & - & 0,11 & 0,54 \\
\hline $\mathrm{MnO}$ & - & - & - & - \\
\hline $\mathrm{MgO}$ & 0,13 & - & - & - \\
\hline $\mathrm{CaO}$ & 23,22 & 22,31 & 22,57 & 23,61 \\
\hline $\mathrm{Na}_{2} \mathrm{O}$ & 0,63 & 0,17 & - & - \\
\hline $\mathrm{K}_{2} \mathrm{O}$ & 0,06 & - & - & - \\
\hline Total & 97,63 & 96,62 & 97,45 & 98,90 \\
\hline \multicolumn{5}{|c|}{ Structural formulae on the basis of 250} \\
\hline $\mathrm{Si}$ & 6,16 & 6,27 & 6,21 & 6,12 \\
\hline \multirow[t]{2}{*}{$\mathrm{Al}^{\mathrm{IV}}$} & - & - & - & - \\
\hline & 6,16 & 6,27 & 6,21 & 6,12 \\
\hline $\mathrm{Al}^{\mathrm{v}} \mathrm{I}$ & 4,31 & 4,52 & 5,01 & 4,10 \\
\hline $\mathrm{Ti}$ & - & 0,01 & - & 0,26 \\
\hline $\mathrm{Fe}^{+3}$ & 1,40 & 1,25 & 0,87 & 1,37 \\
\hline $\mathrm{Cr}$ & 0,04 & - & 0,01 & 0,07 \\
\hline $\mathrm{Mn}$ & - & - & - & - \\
\hline $\mathrm{Mg}$ & 0,03 & - & - & - \\
\hline $\mathrm{Ca}$ & 3,91 & 3,75 & 3,72 & 3,92 \\
\hline $\mathrm{Na}$ & 0,19 & 0,05 & - & - \\
\hline K & 0,01 & - & - & - \\
\hline Ps & 24,51 & 21,66 & 14,79 & 25,04 \\
\hline
\end{tabular}

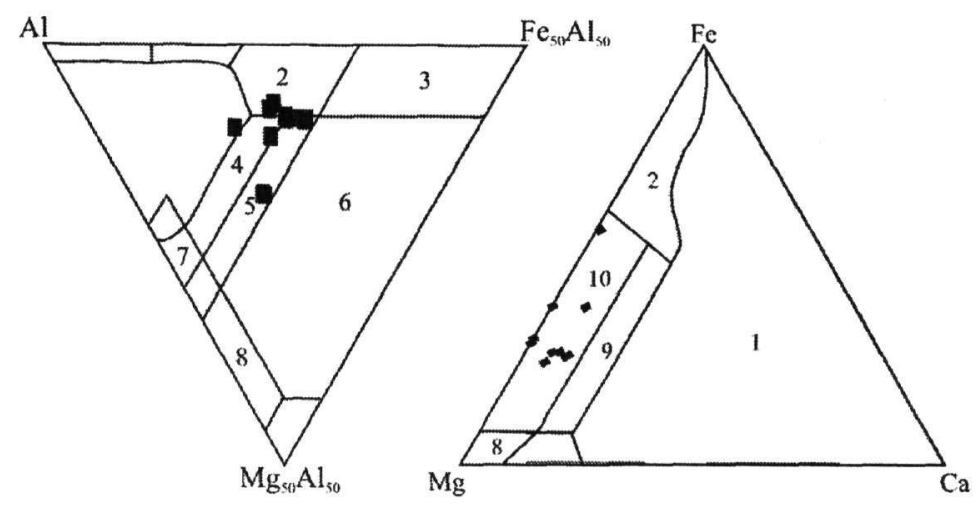




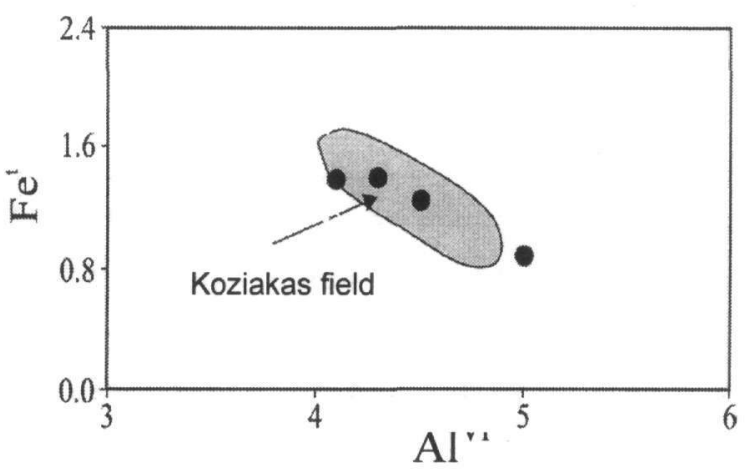

Figure 5. Plot of the analysed epidotes from the Sardinia-Inahos section on a Fe ${ }^{t}$ vs. $\mathrm{Al}^{\mathrm{Vl}}$ diagram. For comparison, the field defined by epidote analyses from the Koziakas ophiolite is shown (data after Pomonis, 2003).

\subsection{Muscovites}

Representative muscovite grain analyses are given in Table 5. The Si/Alv ratio of the studied muscovites is greater than 3, and Si lies between 3.2 and 3.6 (atoms p.f.u., on the basis of 11 oxygens) indicating increased phengitic component (Massone and Shreyer, 1986). Consequently, their original formation is related to relatively high pressure conditions (Guidotti \& Sassi, 1976, Massone \& Schreyer, 1983). Analogous muscovite crystals are widespread in metapelitic rocks from the Pelagonian Zone.

Table 5. Representative muscovite analyses from the Mazia-Votonosi (Mb) and Sardinia - Inahos (A) sections (-: below detection limit).

\begin{tabular}{|c|c|c|c|c|c|c|c|}
\hline Sample & $\mathrm{A} 1$ & A4 & A7 & Mb14 & Mb14 & Mb14 & Mb3 \\
\hline Spot & 1 & 5 & 4 & 2 & 2 & 3 & 3 \\
\hline Pos. & 8 & 2 & 9 & 3 & 4 & 2 & 7 \\
\hline $\mathrm{SiO}_{2}$ & 48,11 & 47,21 & 51,83 & 49,32 & 49,37 & 50,91 & 52,07 \\
\hline $\mathrm{TiO}_{2}$ & 0,82 & 1,15 & - & 0,51 & - & 0,31 & - \\
\hline $\mathrm{Al}_{2} \mathrm{O}_{3}$ & 35,25 & 36,2 & 27,19 & 35,93 & 33,93 & 34,10 & 31,67 \\
\hline $\mathrm{FeO}$ & 1,13 & 0,87 & 2,50 & 0,89 & 2,73 & 2,09 & 2,11 \\
\hline $\mathrm{MnO}$ & - & - & - & - & - & - & - \\
\hline $\mathrm{MgO}$ & 0,76 & 0,70 & 4,08 & 0,27 & 0,61 & 0,69 & 1,74 \\
\hline $\mathrm{CaO}$ & - & - & - & - & - & - & - \\
\hline $\mathrm{Na}_{2} \mathrm{O}$ & 1,58 & 1,79 & 0,88 & 0,57 & 0,58 & 1,04 & 0,55 \\
\hline $\mathrm{K}_{2} \mathrm{O}$ & 9,30 & 8,82 & 10,30 & 9,80 & 9,86 & 8,02 & 9,40 \\
\hline Total & 96,95 & 96,74 & 96,78 & 97,29 & 97,08 & 97,16 & 97,54 \\
\hline \multicolumn{8}{|c|}{ Structural formulae on the basis of 220} \\
\hline $\mathrm{Si}$ & 6,251 & 6,135 & 6,814 & 6,349 & 6,435 & 6,531 & 6,698 \\
\hline \multirow[t]{2}{*}{$\mathrm{Al}^{\mathrm{IV}}$} & 1,749 & 1,865 & 1,186 & 1,651 & 1,565 & 1,469 & 1,302 \\
\hline & 8,000 & 8,100 & 8,000 & 8,000 & 8,000 & 8,000 & 8,000 \\
\hline $\mathrm{Al}^{\mathrm{VI}}$ & 1,710 & 1,744 & 0,973 & 2,051 & 1,796 & 2,042 & 1,759 \\
\hline $\mathrm{Ti}$ & 0,080 & 0,112 & - & 0,049 & - & 0,030 & - \\
\hline $\mathrm{Fe}^{+2}$ & 0,123 & 0,095 & 0,275 & 0,096 & 0,298 & 0,224 & 0,227 \\
\hline Mn & - & - & - & - & - & - & - \\
\hline $\mathrm{Mg}$ & 0,147 & 0,136 & 0,800 & 0,052 & 0,119 & 0,132 & 0,334 \\
\hline $\mathrm{Ca}$ & - & - & - & - & - & - & - \\
\hline $\mathrm{Na}$ & 0,398 & 0,451 & 0,224 & 0,142 & 0,147 & 0,259 & 0,137 \\
\hline $\mathrm{K}$ & 1,542 & 1,462 & 1,728 & 1,61 & 1,64 & 1,313 & 1,543 \\
\hline $\mathrm{Ce}$ & 0,13 & 0,07 & 0,41 & 0,17 & 0,22 & 0,27 & 0,35 \\
\hline $\mathrm{Pg}$ & 20,52 & 23,58 & 11,48 & 8,11 & 8,23 & 16,48 & 8,15 \\
\hline $\mathrm{Mu}$ & 79,36 & 76,36 & 88,12 & 91,72 & 91,56 & 83,26 & 91,50 \\
\hline $\mathrm{Si} / \mathrm{Al}^{\mathrm{IV}}$ & 3,57 & 3,29 & 5,75 & 3,85 & 4,11 & 4,45 & 5,14 \\
\hline
\end{tabular}




\section{DISCUSSION AND CONCLUSIONS}

The detrital grains and lithic fragments found in sandstones from two sections in the Pindos foreland basin provide evidence for tracing the areas that sourced the clastic material. Occurrence of abundant serpentinites and basaltic fragments, as well as detrital spinel grains and calcic plagioclases (particularly the anorthitic one) are all compatible with major supply from ophiolitic sources. Chlorite grains analyses reported by Vakalas (2003) are mainly $\mathrm{Mg}$ - and Si-rich (talc-chlorite), analogous to those occl rring in serpentinized peridotites.

Spinels from both sections show a good relation with these originating from the Pindos ophiolite complex. However, some of the analysed crystals from the Mazia-Votonosi are also related to spinels from the Vourinos ophiolitic complex. The fact that this area is in a distal region, reducing the possibility to work as a feeding source, can be overcome by the presence of Kastaniotikos line, which is a major pathway that transports sediments from distal eastern areas to the west (Vakalas 2003).

Evidence for additional supply of the Sardinia-Inahos section by the Koziakas ophiolite is emerged from the epidote chemistry. Although few crystals were possible to be analysed, it seems that all originate from a unique source, since they form a rather good $\mathrm{Fe}^{\mathrm{t}}-\mathrm{Al}^{\mathrm{V} /}$ linear trend, similar to that formed by epidotes from the Koziakas suite. Moreover, there is strong evidence from study of paleocurrents that supports this hypothesis (Vakalas 2003).

Abundant petrographic evidence is strongly suggestive for a granitic source (i.e. granite fragments, microcline grains, granophyric textures), as well as for a volcanic source of intermediate composition (( $\mathrm{Na}, \mathrm{K})$-feldspar grains). Albite and oligoclase grains could also have been derived by such rocks but since they are also abundant in altered basalts and amphibolitic rocks from the ophiolite suites mentioned above, their occurrence cannot be conclusive. Paleocurrent study of that area revealed that the most probable candidate plutonic body that also supplied the studied areas is the Varnountas plutoric body for te Mazia-Votonosi section and the Pieria or the Verdikousa pluton for the Sardinia-Inahos region (Vakalas 2003).

The involvement of metasedimentary rocks is apparent from the relevant clasts that are found within the collected samples. The analysed detrital muscovites are rather rich in the phengitic molecule, thus indicating a probable derivation from the Pelagonian Zone, where phengitic crystals commonly exist. Tourmaline, although not related to relevant crystals found in-situ, are most probably derived from the same geological area. Supply from the Pelagonian Zone is also suggested from paleocurrent data (Vakalas 2003).

\section{REFERENCES}

Alexander, J., Nichols, G. J., Leigh, S., (1990) The origins of marine conglomerates in the Pindus foreland basin, Greece. Sed. Geol., 66, 243-54

British Petroleum Co Ltd. (B.P.) (1971) The geological results of petroleum exploration in western Greece. Inst. for Geology and Subsurface Research, Special report no. 10, Athens.

Economou, M., Dimou, E., Economou, G., Migiros, G., Vacondios, I., Grivas, E., Rassios, A and Dabitzias, S.,1986. Chromite deposits of Greece. In: Cromites, IGCP 197 (Metallogeny of ophiolites), Athens, 129-159.

Economou-Eliopoulos, M. and Vakondios, I., 1995. Geochemistry of cromites and host rocks from the Pindos ophiolite complex, northwestern Greece. Chemical Geology, 122, 99-108.

Economou-Eliopoulos, M., Tarkian, M. and Sambanis, G., 1999. On the geochemistry of chromites from the Pindos ophiolite complex, Greece. Chemie der Erde, 59, 19-31.

Faupl P., Pavlopoulos A. and Migiros G., 1999. The Paleogene history of the Pelagonian zone S.L. (Hellenides, Greece): Heavy mineral study from terrigenous flysch sediments. Geologica Carpathica , 50, 6, 449-458

Gartzos, E., Migiros, G. and Parcharidis, I., 1990. Chromites from ultramafic rocks of northern Evia (Greece) and their geotectonic significance. Schweiz. Miner. Petrograph. Mitt., 70, 301-307.

Guidotti, C.V. and Sassi, F.P., 1976. Muscovite as a petrogenetic indicator mineral in pelitic schists. N. Jb. Mineral. Abh., 127, 97-142.

Henry, D.J. and Guidotti, C.V., 1985. Tourmaline as a petrogenetic indicator mineral: An example from the staurolite-grade metapelites of NW Maine. Am. Mineral., 70, 1-15.

Hey, M.H., 1954. A new review on the Chlorites. Min. Mag., 224, 277-298.

Leigh, S.P. 1991. The sedimentary evolution of the Pindos foreland basin, western Greece. Ph.D. Thesis, Univ. Wales. 
Massone, H.J. and Schreyer, W., 1986. High pressure syntheses and X-ray properties of white micas in the system $\mathrm{K}_{2} \mathrm{O}-\mathrm{MgO}-\mathrm{Al}_{2} \mathrm{O}_{5}-\mathrm{H}_{2} \mathrm{O}$. N. Jb. Miner. Abh., 153/2, 177-215.

Migiros, G.P., Stasinoulias, E., Stasinoulias, V. and Tsagalidis, A., 1991. The cromite occurrences in the ultrabasic rocks of Southern Pilio. Bull. Geol. Soc. Greece., 25, 2, 321-336.

Pomonis, P., 2003. The Koziakas ophiolite: Geological study, petrogenetic evolution, geotectonic interpretation. Ph.D. Thesis, Univ. Patras, 328pp.

Piper, D. J. W., Panagos, A. G., Pe, G. G., (1978), Conglomeratic Miocene flysch, western Greece. J. Sed. Petr., 48, 117-26

Richter, D., Mariolakos, I., Risch, H. (1978) The main flysch stages of the Hellenides, in: CLOSS, H., ROEDER, D., \& SCHMIDT, K. (Eds) Alps, Apennines, Hellenides, E. Schweizerbatsche Verlagsbuch-handlung, 434438

Vakalas, J., Ananiadis, G., Mpourlokas, J., Poulimenos, D., Getsos, K., Avramidis, P., Zelilidis, A. \& KontopouIos N. 2001. Palaeocurrent directions as an indicator of Pindos foreland evolution (central and southern part), Western Greece. Bulletin of the Hellenic Geological Society, vol. XXXIV/2, 785-791.

Vakalas J.P. , 2003. The Evolution of Foreland Basins in Western Greece, Ph.D thesis, University of Patras, $373 \mathrm{pp}$.

Wilson M. 1989. Igneous petrogenesis. Unwin Hyman, London, 466 pp. 